\title{
SOCIO-ECONOMIC FACTORS INFLUENCING ENTREPRENEURSHIP AMONG WOMEN IN FISHING COMMUNITIES IN ONDO STATE, NIGERIA
}

\author{
Omotoso, F.O. and Daramola, G.A.
}

\begin{abstract}
From the early years till date, Nigerian women in fishing sector remain a potent force in the economic growth of fishing communities. However, many socio-economic factors influence their entrepreneurial skills. This paper examines some objectives such as, what roles do women play in planning and fisheries management? What are the socio-economic factors determining fishing households? What is the allocation of labour/time between productive and non-productive activities? What are the effects of simulated policies on entrepreneurship among the women? Ilaje and Ese-Odo local Government areas of Ondo State are the study areas. One hundred respondents were interviewed in all. Descriptive tools as frequencies, percentages, means and modes were used to analyze the primary data. The study found that overall entrepreneurial rating of the study group is low, essential input can not be easily gotten in the area, the respondents has large household size thereby had a large dependents to take care of, income level is generally low, no modern processing technique and no storage facilities. It also established the need to help them to acquire modern skills hence general improvement in their livelihoods.
\end{abstract}

Keywords: Socio-economic factors, entrepreneurship, fishing communities, women.

\section{INTRODUCTION}

In many developing countries, particularly Nigeria, the involvement of women in agricultural production has been restricted to the provision of family labour, which in most cases is unremunerated. However in some other sub-sectors of the agricultural business such as processing, input distribution and marketing, women have proved to be successful and shrewd investors. The entrepreneurial skills employed in these sub sectors by women can also be brought to bear in agricultural production. (Adekanye, 1989).

Lightfoot (1990) reports that women activities should not be limited as often done in the past to "material" and "domestic" work such as sewing, knitting, food preparation, child care and house keeping. Women must be regarded seriously as producers and be given appropriate training and skills to become more productive in order to contribute more effectively to alleviating the poverty of rural families. The purpose according to Adekanye (1989) is not to remove them from the family to create independent women power but to enhance their productivity in ways that add to their capacity and value within the rural community thus giving them more "bargaining power" for fairer treatment by husbands, mothers-in-law, elders and officials. Therefore if integration of both sexes in public fora is the goal, the means to achieve this may be separate programmes and where mixed programme activities will inhibit women's participation, segregated activities like women associations and clubs may be helpful.

Whether integrated or segregated activities are more beneficial to women depends on the social setting and stage of development, how prepared they are for participation on equal footing with men, and whether they are more likely to develop talents and competence within groups of women or both sexes. Adekanye, (1989). From the standpoint of the society, it is desirable to mobilize all productive resources by engaging women where they earn greatest return IUCN, (1991). The implication is that, if there are efficient women entrepreneurs, and they have better managerial capacities in their respective fields, they ought to be encouraged for the overall benefit of the society. 
By identifying the factors that inhibit the expression of such entrepreneurial skills and taking steps to eliminate them will be a positive development. If the contribution of women to decision-making in planning and management of fishing is widely acknowledge, there is need to examine the problems or constraints being faced by women in organizing their fishing production units. These points are of great importance in developing countries, where everything needs to be done to minimize the time and process of development. It is therefore important to look into the Nigerian women's involvement in fisheries and the factors that influence their entrepreneurial behaviour.

Sirropolis (1990) defines an entrepreneur as one who creates a venture from the raw materials of his/her own ideas and hard work, who is motivated not only by profit but also by "the desire to found a private dynasty, the will to conquer in a competitive battle and the joy of creativity". Entrepreneurship has also been studied as a function of personality traits. (McClelland, 1971; Brockaus, 1982). Other personality traits associated with entrepreneurship are the ability to promote idea and need for control.

From the foregoing discussions, there is a problem with the definition of entrepreneurship in specific term, although each definition captures an aspect of entrepreneurship, none captures the whole picture. In order to facilitate the task of building a more eclectic paradigm of entrepreneurship, it seems that the research agenda must be extended to seek to explain and facilitate the role of the new enterprise in furthering social and economic progress

\section{METHODOLOGY}

The study areas are Ilaje and Ese-odo Local Government areas of Ondo State. The two local Government areas are part of the eighteen local Government areas that make up the State. They are bounded in the North by Ikale Local Government, to the South by the Atlantic Ocean, with a coastline of $80 \mathrm{Km}$ long. This makes Ondo State qualify as a maritime State and makes it rank among the highest fish producers in the country. To the West of the Ilaje Local Government area is Ijebu East Local Government of Ogun State and to the East of Eseode Local Government is Warri Local Government of Delta State.

About $80 \%$ of the Local Government area is covered with water, swamp and flood plains. Rivers largely intersect the area. A vegetation of white mangrove - Aucennia africana and Paspalum vaginatom, characterizes the coastline. Most of the flood plains of the coastal lagoon are covered by Typha, Avstralis and Eichornial crassipes (water hyacinth). The major means of transportation in the study area are motorized canoes, speedboats and paddled canoes. Most of the houses in the coastal and flood plain areas are built on elevated platforms above water level. The area experienced two seasons of the year, dry and rainy seasons that is usually prolonged.

Twenty fishing communities were used for this study and through multi-stage random sampling, five villages were selected. Each village was divided into four wards; five respondents were interviewed from each ward making a total of twenty respondents from each community and one hundred respondents in all. Primary and Secondary data were used for the study. The questionnaires were divided into five sections viz: Socio-economic factors, Production, Infrastructure, Financial/Economics, Support services by Governmental Institutions and Cooperative societies.

It is pertinent to note that the Socio-economic factors were treated simultaneously using the entrepreneurial weighing scale specially designed for this purpose, adapting Daramola (1987). Under the entrepreneurial score method employed in this paper, all the traits are assumed to be divisible and can be represented on a continuous scale. To this end, the maximum entrepreneurial score obtained was fixed at 100, after summing up for all the elements prescribed for entrepreneurship. The choice of 100 is for ease of conversion to the 
probability range. The average value of the weights (assigned for the various entrepreneurial traits) adopted by this study based on sampled opinion of researchers on conversion to the percentage scale is as follows: Asset base-30\%, Technology $-25 \%$, Education-20\%, Experience- $15 \%$ and Diversification-10\%

This procedure assumes that every respondent has an entrepreneurial trait ranging between zero and one hundred (0-100 range). The lower limit was for respondents who has very few of the entrepreneurial traits and the upper limit for respondents operating at the technical optimum levels specified by the modern age fishing science. The level of investment determined each respondent's entrepreneurial trait the respondents "ought" to put into the fishing business based on the recommended level. Therefore, information on the quantity of the same input that the respondents "actually" applied was sought. The ratio of the latter to the former was used to multiply the proportion of yield from the sea attributed to the particular input. The procedure was repeated for all the input to arrive at the total entrepreneurial score for the particular respondent the process can be represented symbolically as:

$$
\begin{array}{r}
\mathrm{Y}_{\mathrm{i}}=\Sigma \\
\mathrm{n}=1 \quad \mathrm{R}_{\mathrm{n}} \quad 100
\end{array}
$$

Where,

$\mathrm{Y}_{\mathrm{i}} \quad=$ Entrepreneurial score for farmer $\mathrm{i}$

$\mathrm{A}_{\text {ni }}=$ Actual level of input, employed by respondent $\mathrm{i}$

$\mathrm{R}_{\mathrm{n}} \quad=$ Recommended level of input

$\Sigma_{\mathrm{n}} \quad=$ Weighted average contribution of input $\mathrm{n}$ to yield from the sea

The necessary statistical test for this study is the Binary-choice model. Several specifications of binary-choice model exist, but the options have been narrowed to both Probit and Logit models.

\section{Description Of Variables}

The Dependent variable: This is entrepreneurship and it is a dichotomous variable capable of taking on a value of either zero or one. A respondent is awarded one if he has a total entrepreneurial score of 35.0 (Cut-off mark) or above 35.0 and Zero, otherwise. Using 35.0 as the cut-off mark is based on the high standard expected of modern age Science of fishing using a high score would exclude many entrepreneurs and help lose relevance.

The Independent Variables: These are the relevant socio-economic factors such as Age of respondents, Education, number of occupation, fishing experience, household size, income, asset, storage facility, processing method, membership of cooperative society, credit availability.

\section{RESULTS}

Demographic factors: This group is based on respondent's personal circumstances and conditions such as: Age, Years of schooling, Occupation(s), Household size, Fishing experience, off fishing income

Age of Respondents: The belief is that the age of an individual affects her mental attitude to risk-taking and new ideas. Evidence from previous works suggests that the older an individual is, the less her willingness to try out new ideas or take risk and the more confidence she gains in her old ways of doing things. Summarily, risk aversion is said to increase with age. The most productive ages of the respondents were between 20-45 years because the women have high mental alertness and physical stability to cope with the rigors of fishing and its related activities. 
Educational level of respondents: This is the period spent by the women receiving education either within a formal school, adult literacy class or Koranic school Education reduces the level of individual ignorance and this in turn improves his ability to decode, make decision, understand and process information. The reason for the result below could be attributed to the fact that most of the people in the study area are traditional fisherwomen; hence a high percentage has no formal education (28\%) (Table 1) and in most cases after primary school, they introduced their wards to full scale fishing business and the young ones are also required for family labour.

\begin{tabular}{lll}
\hline Demographic factors & Frequency & Percentage \\
\hline Educational Level of Respondents & & \\
No Formal Education & 28 & 28 \\
Adult Literacy School & 20 & 20 \\
Primary School & 39 & 39 \\
Modern/Secondary School & 12 & 12 \\
OND/NCE & 1 & 1 \\
Household size (Interval) & & \\
$0-5$ & 12 & 12 \\
$6-10$ & 57 & 57 \\
$11-15$ & 20 & 20 \\
$16-20$ & 6 & 6 \\
$21-25$ & 4 & 4 \\
$26-30$ & 1 & 1 \\
Marital status & & \\
Married & 49 & 49 \\
Single & 20 & 20 \\
Divorced & 12 & 12 \\
Separated & 11 & 11 \\
Widowed & 8 & 8 \\
Income level (N) & & \\
$10,000-20,000$ & 29 & 29 \\
$21,000-30,000$ & 22 & 22 \\
$31,000-40,000$ & 27 & 12 \\
$41,000-50,000$ & 12 & 10 \\
$51,000-60,000$ & 10 &
\end{tabular}

Source Field survey, 2004

Household size of respondents: This is one variable whose influence is so difficult to predict 'a priori'. In the past, the variable used to be positively related to entrepreneurship because of its implication for family labour. These days, however, children attend schools. A negative relationship is therefore expected under the present circumstances because risk aversion increases with increase in household size due to the higher cost

associated with failure to satisfy subsistence food requirement. From this study, the average size of a fishing household membership was between11-15. (Table 2).

This is consistent to the fact that majority of the fishing families are polygamous. According to the men in the communities, "Contrary to the traditional roles of cheap labour, their wives now engage in off-fishing occupation and their children also go to school". By implication, larger household size no longer translates into higher family labour but more responsibilities for the household.

Table 3 shows that $49 \%$ of the women in the study area are married while $20 \%$ are 
single. The effect of this is that, the high percentage of married women in the study area is permanent settlers and migration is not a regular occurrence in the area and all their business activities revolve round the area.

\section{Economic (Wealth related factors)}

These are factors that reflect the level of affluence or economic well being of the respondents. They include factors like fishing income, off-fishing income, and credit availability and market surplus. The average income accruing to the respondents through their fishing activities was N43, 880. This value represents the surplus over subsistence requirement. The modal class for fishing income was N20, 000 as shown in the level of credit available to a particular respondent is also a measure of the respondents worth in financial terms or her borrowing capacity should the need arise.

Generally, the respondents mentioned credit constraints as a major determinant in their fishing business, considering the fact that demand not backed up with purchasing power is ineffective. Considering the level of credit facilities available to the respondents from all sources, (actual and estimates), 2\% had secured bank loans, 10\% had taken loan from cooperative societies, $88 \%$ raised their loans from friends and relatives. Bulk of the artisanal fisher folks in this area is subsistent, which explained why most of the respondents did not have marketable surplus.

\section{Infrastructural Factors}

These are the factors that condition the working environment within which the respondents operate. However, the stock of such facilities available affects the performance and decision making process. The need for proper storage of both the shell and finfishes cannot be overemphasized. $88 \%$ of the people had no storage facilities, they only catch what the household needs to eat and sell the few left to meet their immediate need.

\section{Other Factors}

Labour availability: The general impression among the fisher-folks was that labour was scarce. However most of them did not experience scarcity because their scale of operation was small and use members of their families since most homes in the study area are polygamous in nature.

Cooperative membership: This has always been recommended to the people in the fishing communities. The purpose of the variable is to primarily cater for the interaction and crossfertilization of ideas among the fisher-folks. Generally, issues of mutual interests will feature regularly on their meeting agenda. The early entrepreneurs influence the entrepreneurial behaviors of their 'late' colleagues (laggards) positively. The survey revealed that $37 \%$ of the respondents did not belong to any cooperative society. However, $63 \%$ were members.

Number of occupations: The incidence of multiple occupations is gaining popularity in Nigeria because of the economic situation in the country. Hence, few of the fisher-folks engage in other moneymaking ventures alongside their major fish business. This variable is not familiar in literature and the nature of its influence on entrepreneurship is also unpredictable while diversification can encourage or enhance the risk- taking of the fisherfolks, lack of commitment and subsistence can militate against entrepreneurship.

Off-fishing income: Usually, the higher the fisher-folks off-fishing income is, the more their ability to finance the purchase of fishing inputs. Similarly, the less the fisher-folk's aversion to risk, the higher is the tendency to adopt new innovations. To the contrary, a higher offfishing income, suggests that fishing business is less lucrative, in which case, the women engages in it as a hobby or to meet subsistence needs. In the study area, fishing is the major occupation and the people have very little or no off-fishing income. 
Extension visits per year: Extension personnel are change agents and salesmen of new ideas. They are supposed to visit fishermen and educate them on the importance and applications of new innovation through counseling and demonstrations on a regular basis. However, in the study area, their activities have been on the decline due to lack of fund to finance trips and demonstrations.

Marketable surplus: Most of the women directly involved in fish catching came from the Southeastern and Western parts of the Local Government. Due to the nearness to the Atlantic Ocean and accessibility to brackish water, hence fishing efforts is more intensified there than in the Northern part which is far from the ocean. The fisher-folks subsist on fishing, taking the little left over to the market in exchange for cash. Such women are neither financially strong nor sufficiently convinced to undertake entrepreneurship. The implication of this is that this variable had a positive influence on entrepreneurship in the study area because, it is the surplus produced over and above what is required that is usually marketed. It is the income realized from such marketable surplus that can be re-invested in production.

\section{EMPIRICAL EVALUATION OF RESULTS}

A computer programme known as SHAZAM was used to make the necessary computation for the Logit and Probit analysis for comparison. The programme gave the maximum likelihood estimates of coefficient for the independent variables, the asymptotic standard errors and the t-ratio (ratio of coefficient to their respective standard errors). In the full model, eleven independent variables were considered namely: Age, Education, Household size, Number of occupations, Income, Experience, Asset, Storage, Processing method, Cooperative societies membership and Credit availability.

In search of the 'best' specification that describes the entrepreneurial phenomenon under study; it was one of the primary motives to minimize specification errors due to misspecification bias, either arising from the omission of relevant variable(s). This then dropped to eight variables in the restricted or final model. According to Falusi, (1974). The rule of Thumb was used to exclude all the variables with theoretically (a priori) signs. Namely: Household size, Number of occupations and Education and the new model estimated.

The model's performance was satisfactory, the results of this estimation casts serious doubt on the authenticity of the "a priori" signs of the excluded variables and their coefficients since there is no agreement in entrepreneurship literature as to the direction of their signs. Another criterion used for selecting variables was statistical consideration given as the ratio of the estimated coefficient of their standard errors. The variance-covariance matrices were used to determine the highly correlated variables.

Under the Final modes, all the variables significantly influenced Entrepreneurship at $1 \%$ and $5 \%$ level. Household size was predicted 'a priori' that is, influence is difficult to predict and an earlier arguments suggests that the sign of the coefficient could be positive or negative. With the coefficient taking on a value of -0.07188 , it is apparent that household size has a negative influence on entrepreneurship in this study. Storage from literature is expected to have positive influence on entrepreneurship, but from the study, it had a negative sign, because there were no storage facilities and this further explains why the fisher-folks are not entrepreneurs. 
Table 5: Logit Results (The Full Model)

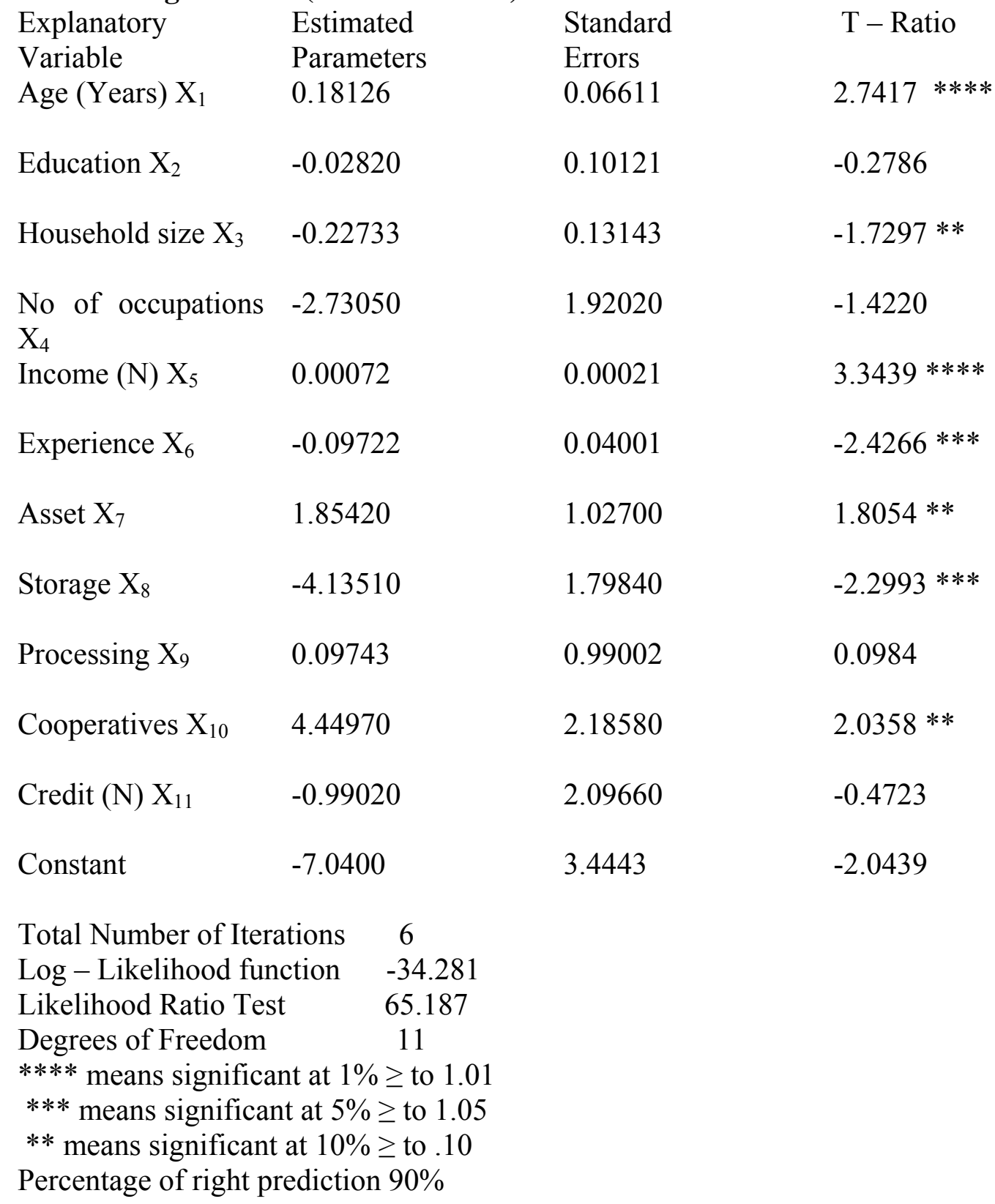


Table 6: Logit Results (The Final Or Restricted Model)

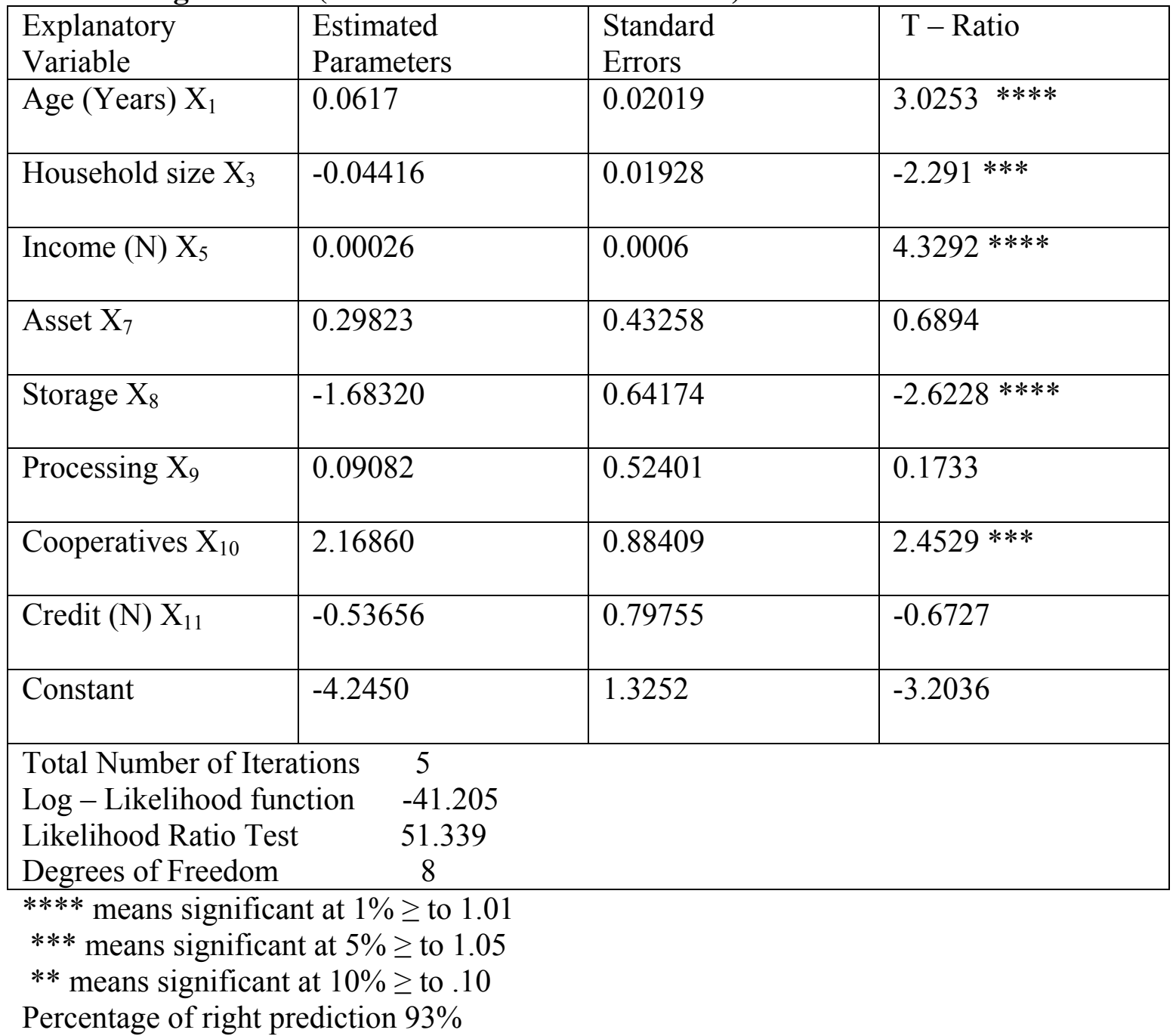

\section{Effects Of Policy Changes}

The effect of policy changes on entrepreneurship through some manipulation of the relevant explanatory variables can be computed. However, absolute changes in the dependent variables often do not fully explain the nature of the relationships between independent and dependent variables. Percentage increases or decreases associated in percentage changes in the independent variables measured about an established point may reveal more information concerning these relationships. The elasticities of entrepreneurial response with respect to any of the variables holding the effects of other constant indicate these percentage changes. In a sense, the magnitude of the elasticity coefficients is thus a reflection of the respondent's entrepreneurial capacity and these elasticity coefficients represent the upper limit of what the respondents can do with respect to the particular variable.

Considering the Weighted Aggregate Elasticities (Table 7), the result shows that any policy legislation that makes the entire respondent to belong to cooperative society will cause an increase of $6 \%$ in the level of entrepreneurs in the study area. So also Age, Income, Asset base and Method of processing will cause an increase of $64 \%, 65 \%, 15 \%$

and $5 \%$ respectively. While with a decrease of $-63 \%,-9 \%$ and $-27 \%$ on Household size, Storage facility and Credit availability among the respondents will cause an increase in entrepreneurship in the area. 
Table 7 Effects of certain policy options on entrepreneurship in the study area

\begin{tabular}{|l|c|c|}
\hline \multicolumn{1}{|c|}{ Policy Set } & Elasticity at Means & $\begin{array}{l}\text { Weighted - Aggregate } \\
\text { Elasticity }\end{array}$ \\
\hline Age & 2.9881 & 1.6465 \\
\hline Income & 1.3221 & 0.6542 \\
\hline Household size & -1.1798 & -0.6300 \\
\hline Asset & 0.2609 & 0.1463 \\
\hline Storage & -0.3681 & -0.0890 \\
\hline Processing & 0.0785 & 0.0478 \\
\hline Cooperative & 1.4940 & 1.0614 \\
\hline Credit & 0.4283 & -0.2745 \\
\hline
\end{tabular}

Source Field survey, 2004

\section{CONSTRAINTS FACING THE RESPONDENTS IN THE STUDY AREA}

The artisans in this area are faced with a lot of constraints, which militate against their maximum productivity and income. Some of these problems are as follows;

High cost of fishing gear: the seaworthy boats are made up of planks, which have become very expensive nowadays. This adds much to the cost of raw materials. Cost of outboard engines has increased more than $300 \%$ in the last couple of years, so the cost of fishing input has gone up astronomically. Access to funds; Poverty is very pronounced in this area and the people do not have access to funds to boost their productivity.

Apart from the ECOWAS fund, which was disbursed by the Nigeria Agricultural Credit Bank (NACB), sometimes ago with only few beneficiaries, some cooperative societies also grant loans to members occasionally.

Labour availability: Apart from its scarcity, labour is very expensive. Labourers are paid either with fish (about $10 \%$ of the catch) or $10 \%$ of the proceeds. They are usually daily paid. In most cases, the young ones are drifting from fishing business to learn other trades that are less hazardous. The graduates of secondary schools also do not wait to take to fishing. They go outside the area to further their education or look for white-collar jobs.

Lack of landing jetties: There are no landing jetties on the whole coast. The only landing facility in the area is the fishing terminal at Igbokoda. Lack of access to the terminal and its distance from the fishing grounds makes it useless for the fisher-folks in this area. One other problem associated with landing in this area is the soft muddy nature of the beach, so the boats anchor some distance to the village and it takes some time before the women comes from the village to evacuate the catch. This adds to the time lag between catch and processing and thereby to spoilage of fish.

Preservation: It is estimated that up to $40 \%$ of the catches are lost to spoilage. Some of the fish caught in the early evening are not taken from the net until 5-6 hours later. The fish gets exposed to the sun, which accelerates spoilage. At the peak of Bonga fishery, the net catches much more than the boat can carry, therefore part of the catches dumped back to the sea and wasted. Processing: This is still done with the traditional smoking kiln, the size of which limits efficiency and quantity of fish that can be processed at a time.

So a lot of the catch is lost to spoilage at this stage. Also, Firewood used for this smoking is getting scarce as a result of reduction of the forest.

Transportation: Majority of the artisanal fisher-folks used dug out canoes, but the wood suitable for the construction of such canoes are also getting scarce as a result of lumbering which fetches more money. Natural disasters: There is a big problem of sea incursion in the eastern part of the coastline of the state. Several villages have been swept away by the sea, and others are been threatened. Villages around Awoye, Oghoye, Ogungbeje are greatly 
affected, so fishermen in this area have lost their homes and fishing equipments. They therefore had to migrate. Water hyacinth also hinders transportation in this area. Oil pollution is another problem in this area. Spillage on the sea infiltrates into the canals and aggravates the pollution caused by the increased number of motorized canoes used for fishing and transportation. All these adversely affect the population of fish and shrimp in the area.

\section{CONCLUSION AND RECOMMENDATIONS}

From the result, it can be concluded that the likely future problem of the study area is the high number of people actually fishing in relation to fish abundance in the coastal waters. It is politically and socially difficult to limit entry into the fisheries because alternative sources of employment and income are scarce particularly for young people in the area. Moreover, the fisher-folks as well as fishing villages are dispersed and either unorganized or only loosely organized. Poor organization of the fishing communities makes it difficult for Government to respond effectively to their needs. The usefulness of this research results in promoting Entrepreneurship in the artisanal fishery in Nigeria. It includes an indication of the depressive and wasteful effects of the absence of inadequate storage facilities. The need to overhaul the infrastructures is a necessity. The dearth of Fisheries extension agents in the riverine areas who are supposed to be "salesmen" of new ideas to the rural dwellers is one of the major setbacks confronting entrepreneurship in the study area. In view of the fact that women play a prominent role in fish processing and marketing in the artisanal fishery of Ilaje and Ese-odo, development assistance to women in this artisanal fishery should be focused on provision of cold store and modern processing facilities.

Traditionally, economic gains are measured in terms of contribution to National economic efficiency. Based on the findings in this study, any policy that is directed at any of the variables has the likelihood of increasing fishing practices, enhancing entrepreneurship, promote self-sufficiency, improves income and living conditions among the fishing populace in Nigeria.

\section{REFERENCES}

Adekanye, T. (1989): "The Role of Women in Agriculture”. Paper presented at workshop on Farm Management in Nigeria. Held at Akure, Nigeria

Benor, D and Baxter, M. (1984) "Training and visit Extension" A World Bank Publications, Washington D.C. USA.

Brockhas, R.H. (1980): "Risk taking Propensity of Entrepreneurs" Academy Of management Journal 23 (3), 509-520

Daramola, A.G. (1987): “A Quantitative Analysis of the Adoption of Improved Food Production Technology in Oyo State, Nigeria" Unpublished Ph.D. Thesis, Department of Agric. Economics, University of Ibadan.

Falusi, A.O. (1974): "Multivariate Probit: Analysis of Selected Factors Influencing Fertilizer Adoption among Farmers in Western Nigeria". Nigeria Journal of Economics and Social Studies. Vol. XVI, NO 1.

IUCN (1991): "Caring for the World: A Strategy for Sustainable Living". World Conservation United Nations Environmental Programme and World Wildlife Fund. Gland, Switzerland.

Lightfoot, A.A. (1990): "Integration of Aquaculture and Agriculture: A Route to

Sustainable Farming Systems.” NAGA, ICLARM, Q. Markafi, Manila, Philippines 13 (1): 9-12

Low. M.B. and Macmillan, I.C. (1988): Entrepreneurship; Past Research and Future. Challenges. Journal of Management 14 (2), 139-161

Pindyck, R.S. and Rubinfield, D.L. (1981):“Economics Models and Economic Forecasts. McGraw-Hill Book Company Inc. $2^{\text {nd }}$ Edition, 630pp 